\title{
Aplikasi Pembelajaran Tatacara Shalat Jumat Berbasis Android
}

\author{
Ferry Dwi Setiyawan ${ }^{1)}$, Rizal Isnanto ${ }^{2)}$, Rinta Kridalukmana ${ }^{2)}$ \\ Jalan Prof. Sudharto, Tembalang, Semarang, Indonesia \\ Ferrysetiyawa@gmail.com
}

\begin{abstract}
For male muslim eid on Friday is obligatory. But in practice there are problems such as application of procedures for Friday prayers is not appropriate and make the pilgrims do not pray with good. For that reason, need a method of learning and innovation easier and more attractive to use technology in the field of islamic learning especially for procedures Friday prayers. As many smartphone users with an operating system android, then made learning application procedures for Friday prayers based on android.

The application of learning is made using software Eclipse IDE and Android SDK with Java as a programming language. Stages of development software used is SDLC (Software Development Life Cycle) by using the method waterfall, as modeling software used is UML (Unified Modelling Language). Steps in this research is software requirement analysis, design, coding, testing and maintenance. Functional testing using a method ofblack box.

The result of this research is application procedures of friday prayers learning based on Android can be use to learning friday prayers. The application can run well on a device with a minimum of android operating system version sandwitch 4.0 (Ice Cream Sandwitch) with the storage space available mb of $7 M B$. Function menus and buttons is going according to their respective functions. This application for procedures of friday prayers can be used as a medium for learning friday prayers.
\end{abstract}

\section{Keywords: Application, Android, Friday Prayer, Eclipse}

\section{PENDAHULUAN}

$\mathrm{S}$ halat Jumat adalah shalat wajib dua rakaat yang dilakukan di hari Jumat secara berjamaah dan didahului dengan dua khutbah. Shalat Jumat merupakan fardhu'ain bagi setiap laki-laki muslim. Fardhu'ain adalah ibadah yang wajib dilakukan oleh setiap orang, dan sama sekali tidak bisa ditinggalkan atau diwakilkan kepada siapa pun. Jika ibadah ini dilaksanakan, maka pelakunya akan mendapatkan pahala, dan jika ditinggalkan, maka pelakunya akan mandapatkan dosa besar. Adapun kewajiban shalat Jumat, Allah Swt. Telah berfirman dalam Q.S al-Jum'ah: 9 yang artinya: "Wahai orang yang beriman, apabila diseru untuk menunaikan sembahyang pada hari jumat, maka bersegeralah kamu kepada mengingat Allah dan tinggalkan jual beli. Yang demikian itu lebih baik bagimu jika kamu mengetahuinya."(Qs. Al-Ju m'ah: 9).

Ayat tersebut memerintahkan manusia untuk mengerjakan shalat Jumat pada hari Jumat. Namun, dengan aktivitas yang padat membuat sebagian orang tidak menjalankannya. Ada pula orang sudah pergi mengerjakan shalat Jumat di masjid hanya sekadar datang, mendengarkan ceramah, dan shalat berjamaah saja namun tidak tahu akan tatacara shalat Jumat yang baik dan benar. Jadi pembelajaran mengenai tatacara shalat Jumat sangat penting bagi jamaah. Pembelajaran tentang tatacara shalat Jumat itu sendiri biasanya melalui buku-buku yang sudah banyak beredar, tetapi kebanyakan orang lebih memilih kepraktisan dari pada dengan membaca buku, misalnya saja dengan menggunakan ponsel cerdas.

Berdasarkan hal tersebut, untuk memenuhi kebutuhan shalat Jumat maka dibuatlah suatu aplikasi pada ponsel cerdas berbasis Android. Aplikasi ini berisikan pembelajaran tatacara shalat Jumat yang dimulai dari syarat syah shalat Jumat, shalat-shalat sunnah dalam shalat Jumat, doa-doa shalat Jumat dan hal-hal yang membatalkan shalat Jumat. Aplikasi ini juga akan dilengkapi dengan gambar dan suara yang mungkin nanti agar para pengguna lebih mudah untuk mempelajari.

\section{LANDASAN TEORI}

\section{A. Definisi Pembelajaran}

Pembelajaran adalah membelajarkan peserta didik menggunakan asas pendidikan maupun teori belajar yang merupakan penentu utama keberhasilan pendidikan. Pembelajaran merupakan proses komunikasi dua arah. Mengajar dilakukan pihak guru sebagai pendidik., sedangkan belajar oleh peserta didik. ${ }^{[13]}$

Mobile Learning (M-Learning) adalah perpaduan atau kombinasi antara Electronic Learning (E-Learning) dan komputer bergerak yang dapat mengakses suatu aplikasi pembelajaran kapanpun dan dimanapun. Perkembangan terbaru dalam teknologi mobile semakin memungkinkan untuk mendukung pembelajaran mobile dan memanfaatkan situasi belajar spontan ini. Selain itu, teknologi mobile menawarkan kesempatan baru untuk mengintegrasikan belajar spontan dalam skenario pembelajaran yang lebih formal. Melihat kecenderungan untuk menggunakan skenario pembelajaran campuran dengan cara menggabungkan bentuk pembelajaran, dan mengintegrasikan berbagai cara untuk mengakses konten, misalnya, berbasis web, desktop, dan mobile. ${ }^{[14]}$

\section{B. Pedoman Shalat Jumat}

Berdasarkan pengertian pentingnya shalat Jumat bagi laklaki muslim maka pembahasan berikutnya tentang shalat Jumat dilan jutkan tentang kedudukannya berdasarkan hokum Islam. Ajaran Islam menyatakan bahwa shalat Jumat merupakan ibadah mahdhah, yang berarti bahwa shalat Ju mat adalah jenis ibadah yang memiliki ketentuan waktu, tempat, dan tata caranya ditetapkan oleh Allah SWT. tanpa ada 
campur tangan pemikiran manusia. Shalat Jumat harus dilakukan oleh setiap laki-laki muslim yang tidak ada udzur untuk meninggalkannya, serta tidak bisa diwakilkan sehingga setiap individu harus melakukannya sendiri secara langsung. Pelaksanaan shalat Jumat harus dilakukan dengan tepat sesuai dengan tuntutan yang telah ditentukan dan dengan tatacara yang benar sehingga amalan atau ibadahnya dapat diterima, dan tidak me lakukannya dengan sia-sia.

Berkaitan dengan kedudukan shalat Jumat, Rasulullah SAW. bersabda tentang peringatan terhadap orang-orang yang meninggalkan shalat Jumat, seperti hadist yang artinya: "Barang siapa meninggalkan tiga kali shalat jumat karena menyepelekannya, maka Allah akan mencap (membekukan) hatinya (sebagai munafik)" (HR. Ahmad). Secara jelas, hadist tersebut menyatakan bahwa orang yang meninggalkan shalat Jumat tiga kali tanpa ada udzur, maka dicap sebagai munafik, dan hakikat munafik adalah kafir. Orang munafik mempunyai indikasi sebagai musuh dalam selimut terhadap Allah dan Rasul, serta umat Islam. Allah SWT. memberikan balasan yang sangat pedih sebagaimana dalam Q.S. an-Nisa 145 yang artinya: "Sesungguhnya orang-orang munafik itu ditempatkan di tingkat yang paling bawah dari Neraka Jahanam. Kamu tidak dapat menolong keadaan mereka”.

Kedudukan shalat Jumat sangat penting bagi umat Islam karena ancaman Allah sangat tegas terhadap orang-orang yang secara sengaja meninggalkan shalat Jumat. Disamping harus mengetahui hukum dan kedudukan shalat jumat diharuskan juga memahami secara benar tentang rukun, syarat, adab, dan hal-hal yang berkaitan dengan pelaksanaan ibadah shalat Jumat agar dapat ditunaikan dengan sah dan sempurna sesuai dengan yang disyariatkan. ${ }^{[4]}$

\section{Android}

Android adalah sistem operasi untuk telepon seluler yang berbasis Linux. Android menyediakan platform terbuka bagi para pengembang untuk menciptakan aplikasi mereka sendiri untuk digunakan oleh bermacam peranti bergerak. Google Inc. membeli Android Inc., pendatang baru yang membuat peranti lunak untuk ponsel. Kemudian untuk mengembangkan Android, dibentuklah Open Handset Alliance, konsorsium dari 34 perusahaan peranti keras, peranti lunak, dan telekomunikasi, termasuk Google, HTC, Intel, Motorola, Qualcomm, T-Mobile, dan Nvidia.

Pada saat perilisan perdana Android, tahun 2007, Android bersama Open Handset Alliance menyatakan mendukung pengembangan standar terbuka pada perangkat seluler. Di lain pihak, Google merilis kode-kode Android di bawah lisensi Apache, sebuah lisensi perangkat lunak dan standar terbuka perangkat seluler. ${ }^{[8]}$

Setiap versi Android telah dirilis di bawah nama kode berdasarkan makanan penutup, seperti eclair, Froyo, Gingerbread, dll. Adapun versi - versi android yang pernah dirilis adalah sebagai berikut :

1. Android versi 1.1

2. Android versi 1.5 (Cupcake)

3. Android versi 1.6 (Donut)

4. Android versi $2.0 / 2.1$ (Éclair)

5. Android versi 2.2 (Frozen Yoghurt)

6. Android versi 2.3 (Gingerbread)

7. Android versi 3.0 (Honeycomb)

8. Android versi 4.0 (Ice Cream Sandwich)

9. Android versi 4.1/4.2/ 4.3 (Jelly Beans) ${ }^{[8]}$

\section{Java}

Java merupakan bahasa pemrograman yang diciptakan oleh James Gosling pada tahun 1996. Sampai saat ini pengembangan Java berada dibawah Sun Microsystem walaupun akhir-akhir ini Java mu lai di open-sourcekan. Java dapat diimplementasikan pada berbagai aspek kehidupan mulai dari komputer mainframe, PC, telepon genggam/HP, PDA, s mart card sampai dengan perlengkapan rumah tangga seperti mesin cuci dan TiVo. Java menjanjikan sifat platform independent yang berarti program cukup ditulis satu kali dan dicompile satu kali maka akan dapat dijalankan di mesin lain tanpa memerlukan pengubahan kode. ${ }^{[3]}$

Kelebihan Pemograman Java:

1. Kelebihan utama dari Java ialah dapat dijalankan di beberapa platform/ sistem operasi komputer, sesuai dengan prinsip tulis sekali, jalankan di mana saja. Dengan kelebihan ini pemrogram cukup menulis sebuah program Java dan dikompilasi (diubah, dari bahasa yang dimengerti manusia menjadi bahasa mesin bytecode) sekali lalu hasilnya dapat dijalankan di atas beberapa platform tanpa perubahan. Kelebihan ini memungkinkan sebuah program berbasis java dikerjakan diatas operating system Linux tetapi dijalankan dengan baik di atas Microsoft Windows. Platform yang didukung sampai saat ini adalah Microsoft Windows, Linu x,Mac OS dan Sun Solaris.

2. Perpustakaan kelas yang lengkap, Java terkenal dengan kelengkapan library/ perpustakaan (kumpulan program program yang disertakan dalam pemrograman java) yang sangat memudahkan dalam penggunaan oleh para pemrogram untuk membangun aplikasinya. Kelengkapan perpustakaan ini ditambah dengan keberadaan komunitas Java yang besar yang terus menerus membuat perpustakaan-perpustakaan baru untuk melingkupi seluruh kebutuhan pembangunan aplikasi.

3. Bahasa pemograman $\mathrm{C}++$ sehingga menarik banyak pemrogram $\mathrm{C}++$ untuk pindah ke Java. Saat ini pengguna Java sangat banyak, sebagian besar adalah pemrogram $\mathrm{C}++$ yang pindah ke Java ${ }^{[6]}$

\section{E. Eclipse IDE}

Eclipse Integrated Development Environment (Eclipse IDE) adalah program komputer yang memiliki beberapa fasilitas yang diperlukan dalam pembangunan perangkat lunak. Tujuan dari IDE adalah untuk menyediakan semua utilitas yang diperlukan dalam me mbangun perangkat lunak.

Eclipse merupakan IDE yang paling banyak diadopsi untuk programmer Java. Dan sekarang Eclipse adalah IDE yang lebih disukai untuk mengembangkan aplikasi android. Eclipse menyediakan lingkungan yang komprehensif bagi pengembang Android untuk membuat aplikasi. Berikut ini adalah sifat dari Eclipse:

1. Multi-platform: Target sistem operasi Eclipse adalah Microsoft Windows, Linu x, Solaris, AIX, HPUX dan Mac OS X.

2. Mulit-language: Eclipse dikembangkan dengan bahasa pemrograman Java, akan tetapi Eclipse mendukung pengembangan aplikasi berbasis bahasa pemrograman lainnya, seperti $\mathrm{C} / \mathrm{C}++$, Cobol, Python, Perl, PHP, dan lain sebagainya.

3. Multi-role: Selain sebagai IDE untuk pengembangan aplikasi, Eclipse pun bisa digunakan untuk aktivitas dalam siklus pengembangan perangkat lunak, seperti dokumentasi, test perangkat lunak, pengembangan web, dan lain sebagainya. ${ }^{[2]}$ 


\section{PERANCANGAN SISTEM}

\section{A. Perancangan Menggunakan Metode Waterfall}

Metode waterfall adalah metode yang menyarankan sebuah pendekatan sistematis dan sekuensial melalui tahapantahapan yang ada pada SDLC untuk membangun sebuah perangkat lunak. Metode ini memberikan pendekatanpendekatan sistematis dan berurutan bagi pengembangan perangkat lunak. Model waterfall terdiri dari 4 tahap yaitu Analisis, Desain, Pengodean, Pengujian dan Pemeliharaan

\section{B. Analisis Kebutuhan}

Sistem yang dibuat seringkali tidak sesuai dengan keinginan dari pengguna sistem yang memungkinkan terjadi kesalahan. Hal ini sering terjadi apabila dalam pembuatan sebuah sistem tidak diawali dengan analisis kebutuhan yang mendasar dan rinci. Analisis kebutuhan dapat dilakukan melalui wawancara dengan pihak-pihak terkait dan pengamatan dari lingkungan di mana sistem akan dibangun.

Aplikasi yang akan dibuat merupakan sebuah sistem pembelajaran tatacara shalat Jumat pada perangkat bergerak berbasis Android. Aplikasi in i dibuat berbasis mobile dengan perangkat pengembangan Eclipse dan pemrograman bahasa Java.

Beberapa kebutuhan non fungsional perihal pengembangan aplikasi.

1) Notebook TOSHIBA Satellite L510 Intel $\mathbb{R}$ Core $^{\mathrm{TM}} 2$ Duo Processor T6500:2.10 GHz

2) Sistem Operasi : Microsoft Windows 7 Professional

3) Ponsel pintar Lenovo P770 dengan OS Android Jelly Bean dan RAM 1 GB

4) Eclipse IDE

5) Android SDK

6) Corel Draw

\section{Desain}

Perancangan konseptual meliputi desain proses dari sistem. Desain proses dibuat berdasarkan kebutuhan fungsional dan kebutuhan data. Aliran Sistem digambarkan dengan menggunakan UML (Unified Modelling Language)

\section{Use Case Diagram}

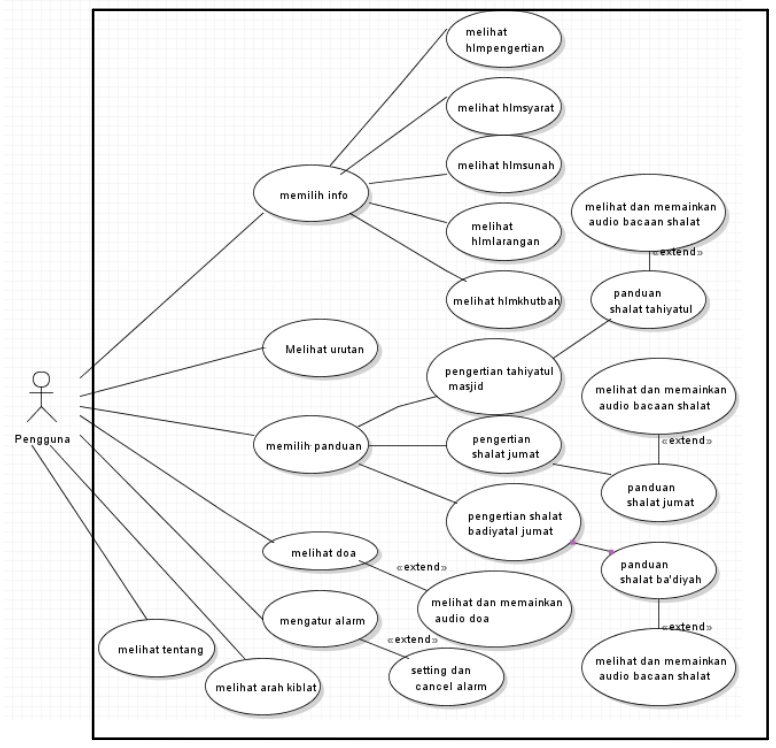

Gambar 1. Diagram Use case

\section{Sequence Diagram}

Sequence Diagram menggambarkan fungsionalitas dari masing-masing use case dan interaksi yang terjadi antar objek dalam sistem.

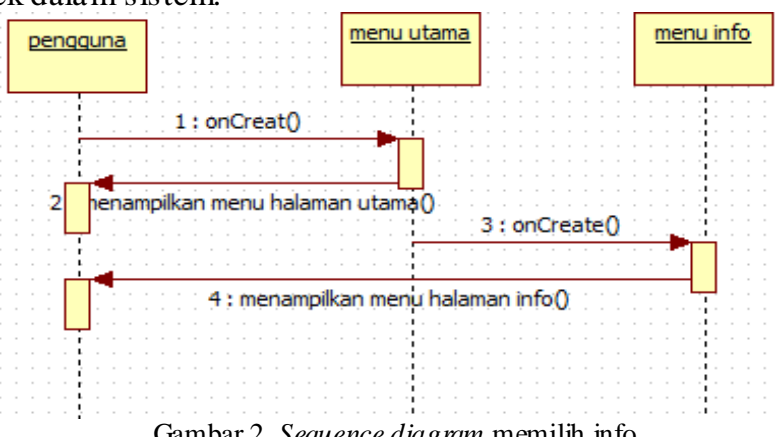

Gambar 2. Sequence diagram memilih info

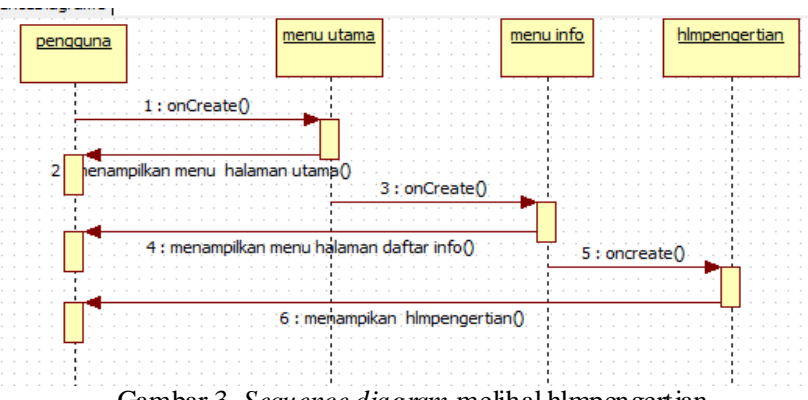

Gambar 3. Sequence diagram melihal hlmpengertian

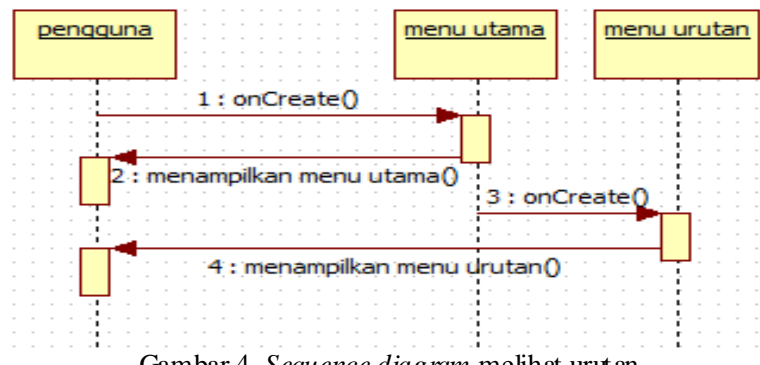

Gambar 4. Sequence diagram melihat urutan
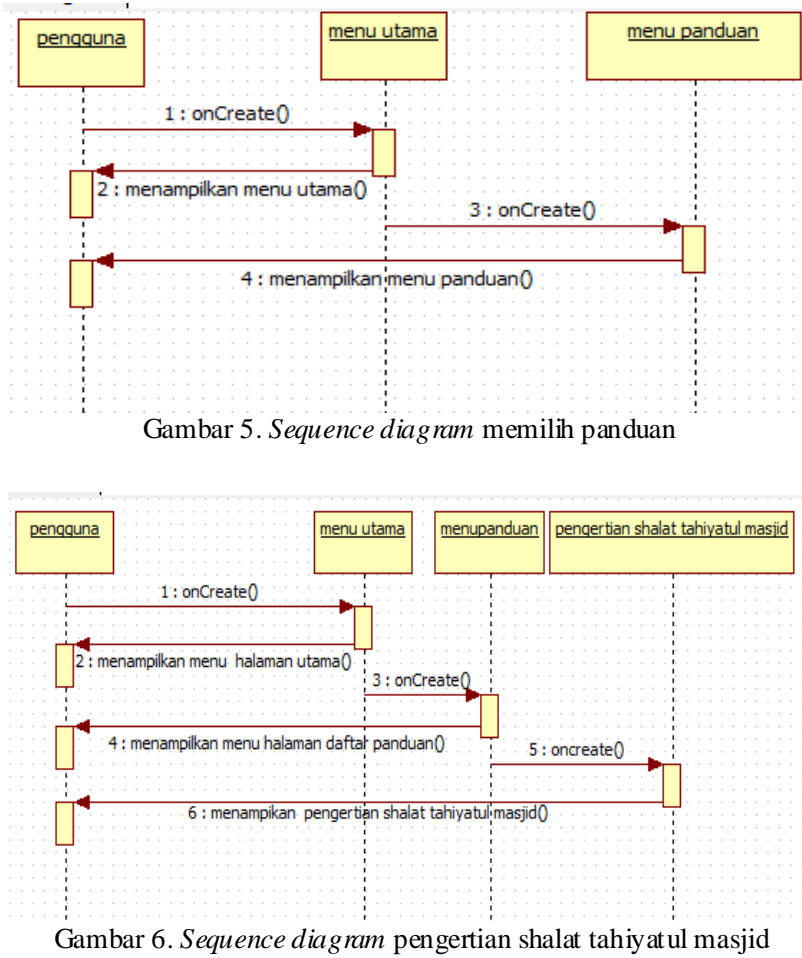

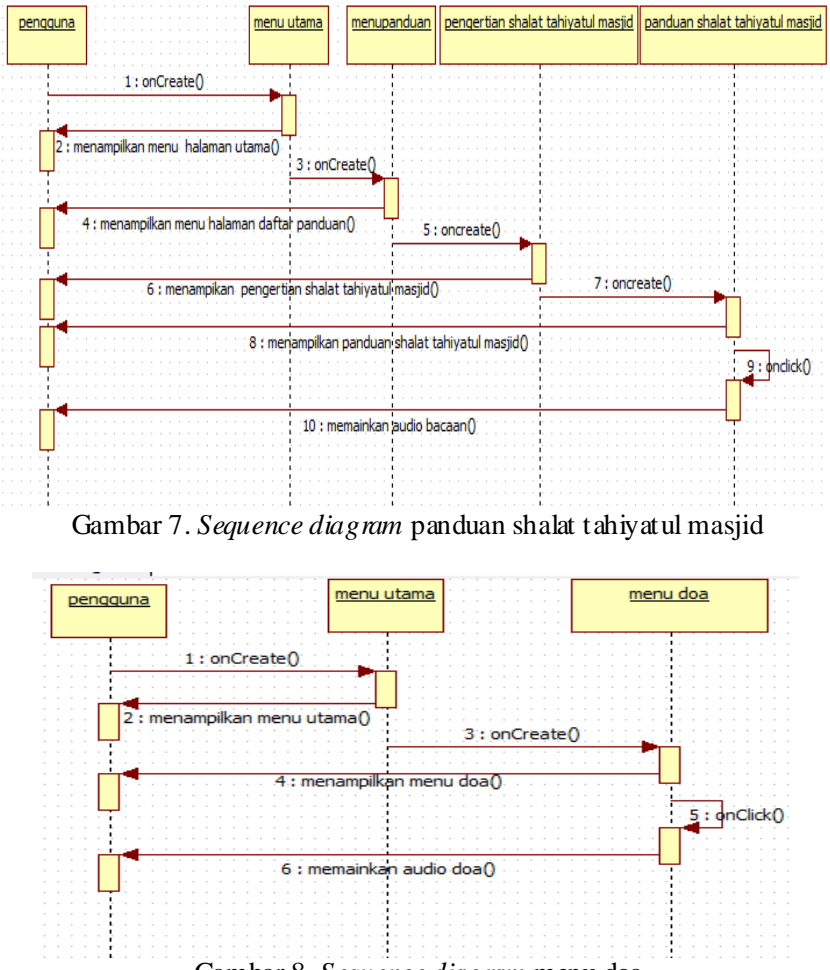

Gambar 8. Sequence diagram menu doa

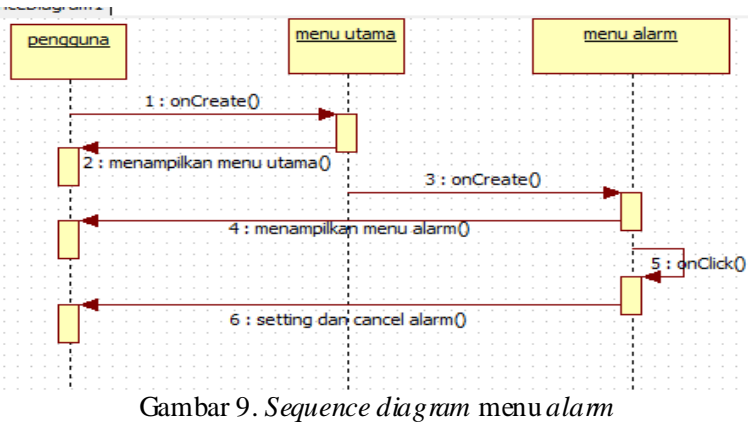

Gambar 9. Sequence diagram menu alam

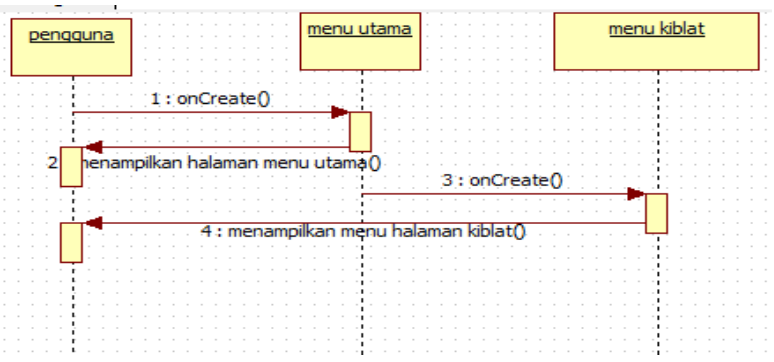

Gambar 10. Sequence diagram menu arah kiblat

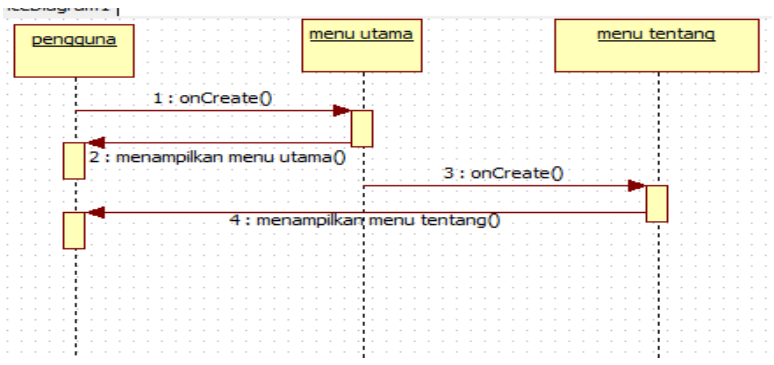

Gambar 11. Sequence diagram menu tentang

3. Diagram Kelas

Class adalah sebuah spesifikasi yang jika diinstansiasi akan menghasilkan sebuah objek dan merupakan inti dari pengembangan dan desain berorientasi objek. Class menggambarkan keadaan (atribut/properti) suatu sistem, sekaligus menawarkan layanan untuk memanipulasi keadaan tersebut (metode/fungsi).
4.Perancangan Antarmuka

Perancangan antarmuka yang baik bersifat kritis bagi keberhasilan suatu sistem. Antarmuka adalah suatu bagian yang berhubungan langsung dengan pengguna aplikasi. Rancangan antarmuka yang buruk dapat mengakibatkan kesalahan yang fatal dapat mengurangi fungsional aplikasi.

Menu Utama merupakan tampilan yang akan tampil sebagai halaman utama pada aplikasi. Pada halaman utama/menu utama ini terdapat beberapa tombol menu pilihan. Gambar 12 merupakan tampilan rancangan menu utama.

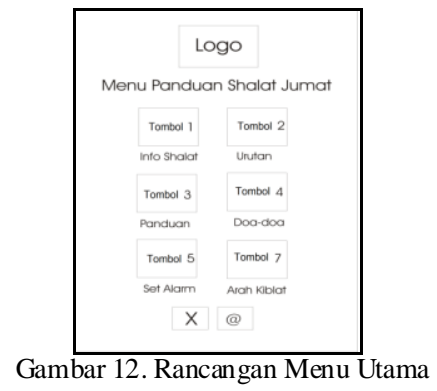

Menu Info merupakan tampilan yang akan tampil setelah mengklik tombol Info pada menu Utama Shalat Jumat. Gambar 13 merupakan tampilan rancangan menu Info.

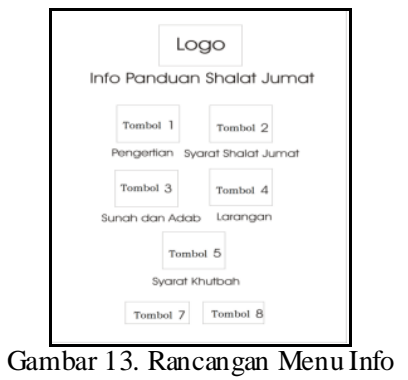

Halaman Pengertian Shalat Jumat akan muncul ketika pengguna menekan tombol menu Pengertian pada menu Info. Gambar 14 merupakan tampilan rancangan halaman pengertian.

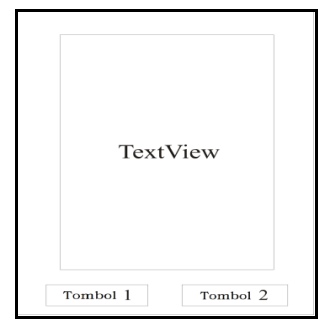

Gambar 14. Rancangan Halaman Pengertian

Menu Urutan merupakan menu yang menjelaskan urutan atau alur dalam pelaksanakan shalat Jumat, akan muncul ketika pengguna menekan tombol Urutan pada menu Utama. Terdapat tombol 1 merupakan to mbol Kembali dan tombol 2 yaitu tombol menu Utama.Gambar 15 menunjukkan rancangan halaman menu Urutan shalat Jumat.

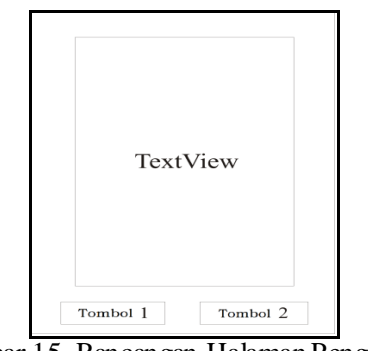

Gambar 15. Rancangan Halaman Pengertian 
Menu Panduan merupakan tampilan yang akan tampil setelah mengklik to mbol Panduan pada menu Utama shalat Jumat. To mbol 1(shalat tahiyatul masjid ), to mbol 2 ( shalat jumat) dan tombol 3 (Shalat ba'diyah jumat). Gambar 16 menunjukkan rancangan menu Panduan shalat Jumat.

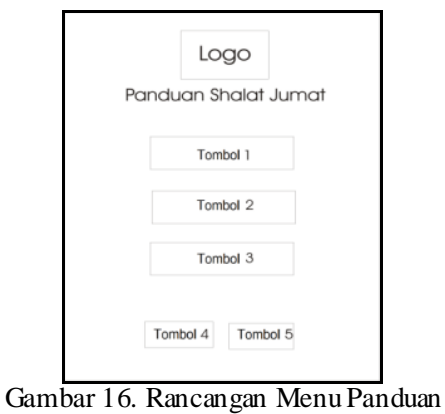

Menu Pengertian Shalat Tahi yatul Masjid merupakan menu yang menjelaskan tentang pengertian shalat tersebut, akan muncul ketika pengguna menekan tombol shalat tahiyatul masjid pada menu Panduan Shalat. Terdapat tombol 1 merupakan tombol Kembali dan tombol 2 yaitu tombol Lanjut. Gambar 17. menunjukkan rancangan Menu Pengertian Shalat Tahi yatul Masjid.

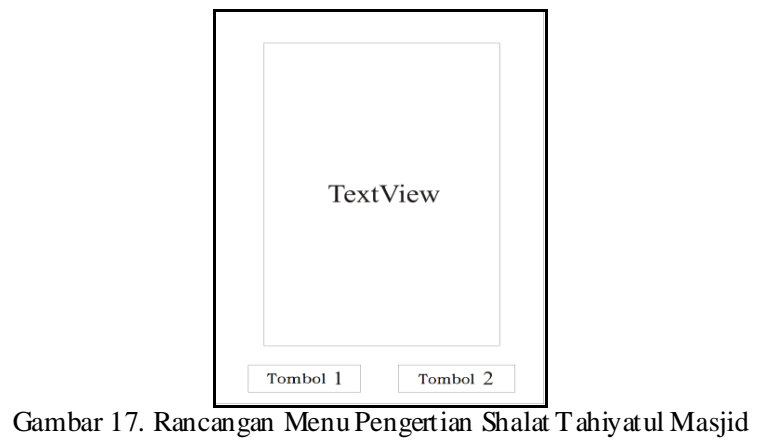

Menu Panduan Shalat Sunah Tahiyatul Masjid merupakan menu yang menjelaskan tentang tatacara shalat tahiyatul masjid yang berupa gambar gerakan shalat, bacaan dalam bahasa arab, bacaan dalam bahasa latin, arti dan audio bacaan shalat. Play merupakan tombol yang digunakan untuk memberi perintah untuk menjalankan audio bacaan. Stop tombol yang berfungsi untuk memberi perintah stop pada bacaan ketika audio bacaan sedang berjalan. Gambar 18 . menunjukkan rancangan menu Panduan Shalat Sunah Tahiyatul Masjid.

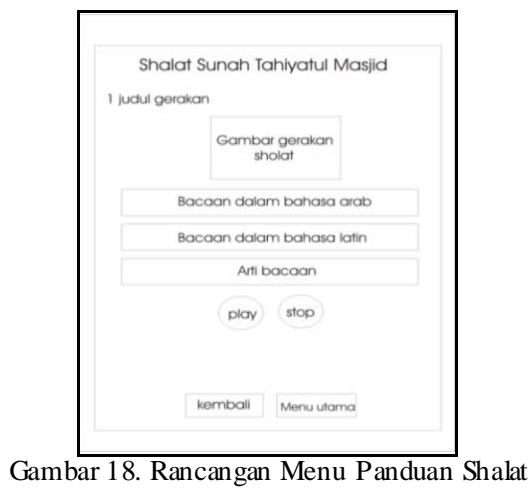

Menu Doa-doa merupakan menu yang menampilkan doa-doa dalam shalat Jumat. Menu Doa-doa akan muncul bila pengguna menekan to mbol Doa-Doa dalam menu
Utama maka menu Doa-doa akan muncul. Di dalam perancangan ini terdapat play merupakan tombol yang digunakan untuk memberi perintah untuk menjalankan audio bacaan. Tombol Stop berfungsi untuk me mberi perintah stop pada bacaan ketika audio bacaan sedang berjalan. Gambar 19 menunjukkan rancangan menu Doa-doa.

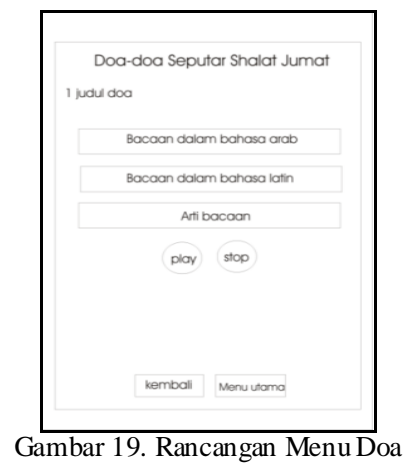

Menu Alarm merupakan menu pengingat bilamana shalat Jumat telah tiba untuk memuncukan menu ini pengguna menekan tombol Set Alarm pada menu Utama. Gambar 20. menunjukkan rancangan halaman menu Alarm.

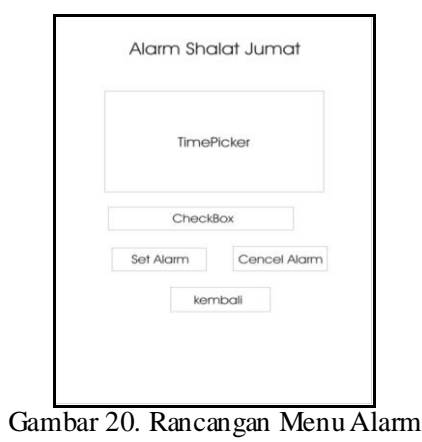

Menu Arah Kiblat merupakan menu yang menunjukan arah kiblat. Menu ini akan muncul bila pengguna menekan tombol Arah Kiblat pada menu Utama. Perancanga arah kiblat dapat di lihat pada Gambar 21. menunjukkan rancangan menu Arah Kiblat.

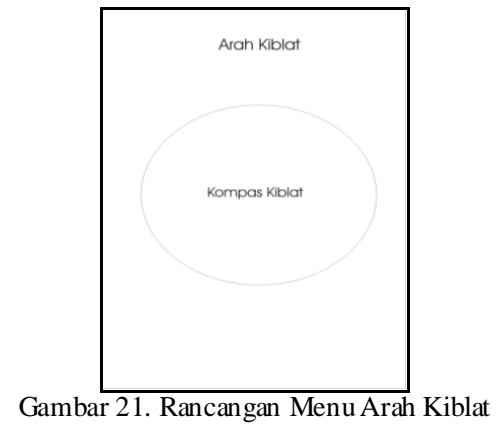

\section{IMPLEMENTASI DAN PENGUJIAN}

\section{A. Implementasi}

Implementasi antarmuka merupakan penerapan dari rancangan antarmuka Aplikasi Pembelajaran Tatacara Shalat Jumat. Implementasi antarmu ka yang menarik dan pengguna sangat penting dalam membangun sebuah aplikasi. Dengan antarmuka yang menarik dan pengguna dapat memberikan daya tarik kepada pengguna untuk menggunakan aplikasi. 


\section{1) Tampilan Splash Screen}

Tampilan awal aplikasi pe mbelajaran tatacara shalat Ju mat berupa splash screen. Tampilan splash screen ini merupakan tampilan pembuka Aplikasi Pembelajaran Tatacara Shalat Jumat. Tampilan splash screen dapat dilihat pada Gambar 22.

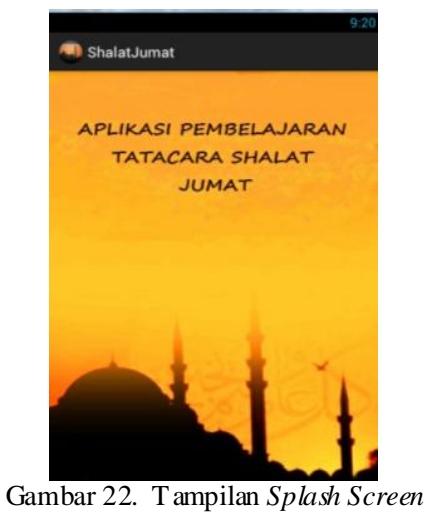

\section{2) Tampilan Menu Utama}

Tampilan menu Utama merupakan tampilan yang digunakan sebagai halaman awal Aplikasi Pembelajaran Tatacara Shalat Jumat. Tampilan menu Utama ini akan muncul setelah tampilan splash screen tertutup. Pada tampilan menu Utama terdapat tombol-tombol untuk masuk ke halaman menu-menu yang lain. Tampilan menu Utama dapat di lihat pada Gamabr 23.

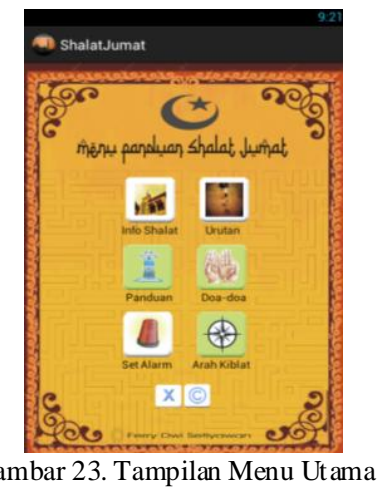

3) Tampilan Menu Info

Tampilan menu Info merupakan tampilan yang menjelaskan berbagai informasi mengenai shalat jumat. Tombol-tombol yang tersedia pada menu Info akan menjelaskan mengenai Info Shalat Jumat, tombol yang tersedia tombol Pengertian, to mbol Syarat Shalat Jumat, tombol Sunnah dan Adab, tombol Larangan dan tombol Khutbah. Tampilan menu Info dapat dilihat pada Gambar 24.

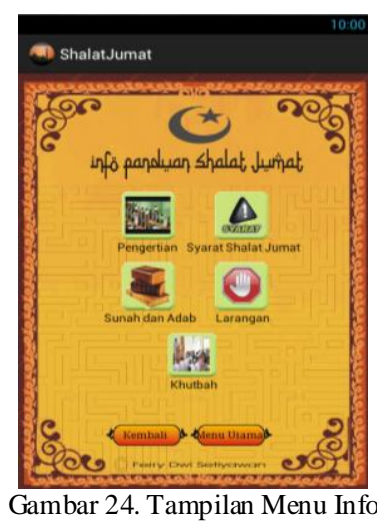

4) Tampilan Halaman Pengertian

Tampilan halaman pengertian berisi penjelas an mengenai definisi shalat Ju mat. Tampilan ini dapat dilihat pada Gambar 25 .

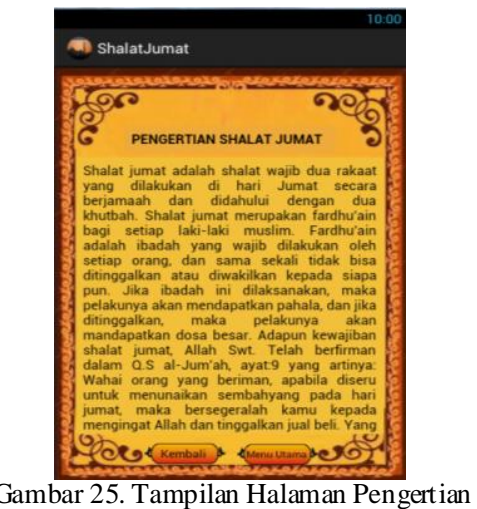

\section{5) Tampilan Menu Urutan}

Tampilan halaman menu Urutan berisi penjelasan mengenai urutan atau rentetan acara dalam melaksanakan shalat Jumat. Tampilan menu Urutan dapat dilihat pada Gambar 26.

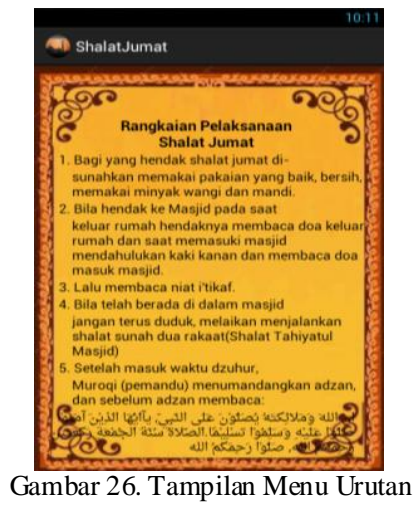

6) Tampilan Menu Panduan

Tampilan menu Panduan merupakan tanpilan yang menjelaskan tentang panduan mengenai shalat Jumat yang terdiri dari to mbol shalat tahiyatul masjid, shalat Jumat dan shalat ba'diyah Jumat. Tampilan menu Panduan dapat dilihat pada Gambar 27.

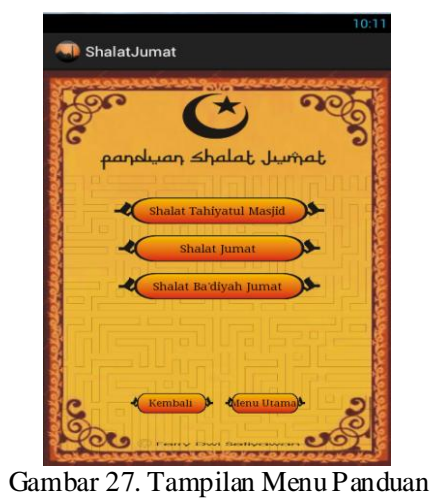

\section{7) Tampilan Menu Shalat Tahiyatul Masjid}

Pada tampilan menu Shalat Tahiyatul Masjid terdapat penjelasan mengenai shalat tahiyatul masjid dalam shalat jumat dan terdapat panduan shalat tahiyatul masjid yang dilengkapi dengan gambar, bacaan arab, bacaan latin, arti dan audio bacaan. Gambar 28. (a) menunjukkan tampilan penjelasan shalat tahiyatul masjid. Gambar 28. (b). menunjukkan tampilan panduan shalat tahiyatul masjid. 


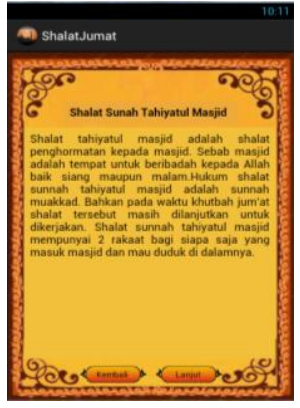

(a)

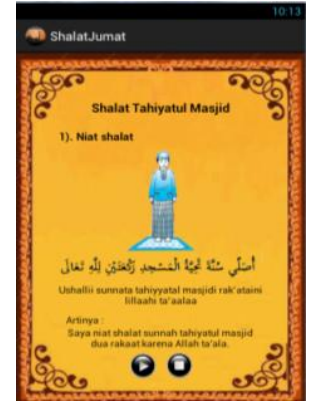

(b)
Gambar 28. (a) Tampilan Halaman Pengertian, (b) Panduan Shalat Tahiyatul Masjid

8) Tampilan Menu Doa-doa

Tampilan halaman menu Doa-doa berisikan mengenai doa-doa seputar shalat Jumat dan dilengkapi dengan bacaan dan audio bacaan doa. Tampilan menu Doa-doa dapat dilihat pada Gambar 29

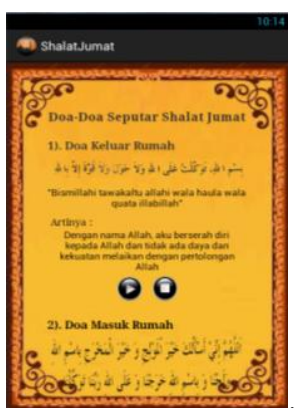

Gambar 29. Tampilan Menu Doa-doa

\section{9) Tampilan Menu Set Alarm}

Tampilan halaman menu Set Alarm difungsikan sebagai pengingat atau alarm sebelum shalat Jumat dimulai. Tampilan menu Set Alarm dapat dilihat pada Gambar 30. (a) dan saat alarm berbunyi terliahat pada Gambar 30. (b).

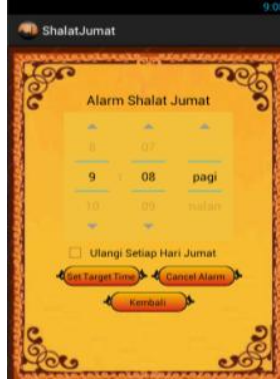

(a)

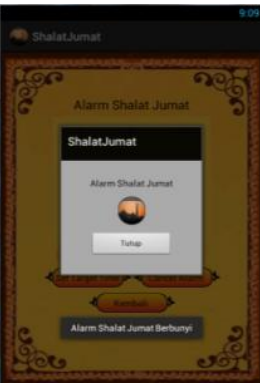

(b)
Gambar 30. (a) Tampilan Set Alarm, (b) Tampilan Alarm Berbunyi

\section{0) Tampilan Menu Arah Kiblat}

Tampilan halaman menu Arah Kiblat difungsikan sebagai petunjuk arah kiblat shalat. Tampilan menu Arah Kiblat dapat dilihat pada Gambar 32.

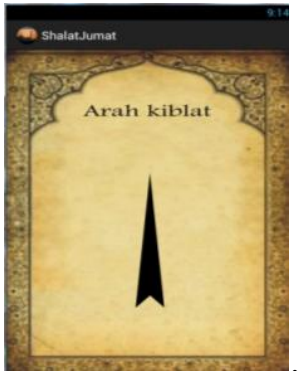

Gambar 31. Tampilan Menu Arah Kiblat
11) Tampilan Menu Tentang

Tampilan halaman menu Tentang berisi mengenai tentang aplikasi. Tampilan menu Tentang dapat dilihat pada Gambar 32.

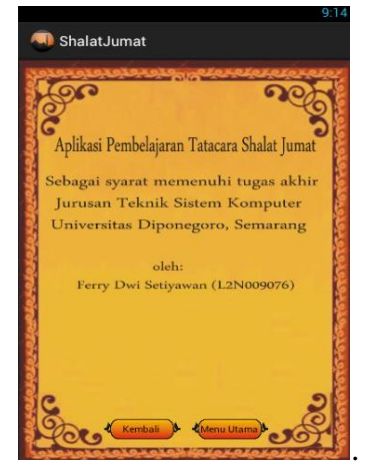

Gambar 32. Tampilan Menu Tentang

\section{B. Pengujian}

Tahap pengujian yang dilakukan adalah menggunakan pengujian metode black-box yaitu menguji fungsionalitas dari perangkat lunak. Pengujian black-box digunakan untuk menemukan kesalahan-kesalahan seperti fungsi yang tidak sesuai serta kesalahan antarmuka.

TABEL 1

PENGUJIAN SISTEM

\begin{tabular}{|c|c|c|}
\hline Pengujian & Detail Pengujian & $\begin{array}{c}\text { Jenis } \\
\text { Uji }\end{array}$ \\
\hline Splash screen & Menampikan Splash screen & $\begin{array}{c}\text { Black- } \\
\text { box }\end{array}$ \\
\hline Menu Utama & $\begin{array}{l}\text { Menampilkan halaman menu } \\
\text { Utama dengan beberapa } \\
\text { menu dida lamnya yaitu: Info, } \\
\text { Urutan, Panduan, Doa-doa, } \\
\text { Set Alarm, Tentang dan } \\
\text { Keluar. }\end{array}$ & $\begin{array}{l}\text { Black- } \\
\text { box }\end{array}$ \\
\hline Menu Info & $\begin{array}{l}\text { Menampilkan menu Info } \\
\text { dengan beberapa menu di } \\
\text { dalamnya diantaranya } \\
\text { pengertian, syarat, sunah, } \\
\text { larangan dan khutbah }\end{array}$ & $\begin{array}{l}\text { Black- } \\
\text { box }\end{array}$ \\
\hline $\begin{array}{c}\text { Menu } \\
\text { Pengertian }\end{array}$ & $\begin{array}{l}\text { Menampilkan penjelasan } \\
\text { mengenai pengertian shalat } \\
\text { ju mat }\end{array}$ & $\begin{array}{l}\text { Black- } \\
\quad \text { box }\end{array}$ \\
\hline Menu Syarat & $\begin{array}{l}\text { Menampilkan mengenai } \\
\text { syarat-syarat yang ada di } \\
\text { dalam shalat ju mat. }\end{array}$ & $\begin{array}{l}\text { Black- } \\
\text { box }\end{array}$ \\
\hline Menu Sunah & $\begin{array}{l}\text { Menampilkan mengenai } \\
\text { sunah dan adab dalam shalat } \\
\text { jumat }\end{array}$ & $\begin{array}{l}\text { Black- } \\
\text { box }\end{array}$ \\
\hline $\begin{array}{c}\text { Menu } \\
\text { Larangan }\end{array}$ & $\begin{array}{l}\text { Menampilkan mengenai } \\
\text { larangan yang ada dalam } \\
\text { shalat jumat }\end{array}$ & $\begin{array}{l}\text { Black- } \\
\text { box }\end{array}$ \\
\hline $\begin{array}{c}\text { Menu } \\
\text { Khutbah }\end{array}$ & $\begin{array}{l}\text { Menampikan syarat, sunah } \\
\text { dan rukun khutbah dalam } \\
\text { shalat jumat }\end{array}$ & $\begin{array}{l}\text { Black- } \\
\text { box }\end{array}$ \\
\hline
\end{tabular}




\begin{tabular}{|c|c|c|}
\hline $\begin{array}{c}\text { Menu } \\
\text { Panduan }\end{array}$ & $\begin{array}{l}\text { Menampilkan halaman menu } \\
\text { Panduan dengan beberapa } \\
\text { menu dida lamnya yaitu: } \\
\text { Shalat Tahiyatul masjid, } \\
\text { Shalat Ju mat, dan shalat } \\
\text { Ba'diyah Jumat. }\end{array}$ & Black-box \\
\hline $\begin{array}{l}\text { Pengertian } \\
\text { Shalat } \\
\text { Tahiyatul } \\
\text { Masjid }\end{array}$ & $\begin{array}{l}\text { Menampilkan penjelasan } \\
\text { mengenai shalat tahiyatul } \\
\text { masjid di dalam shalat } \\
\text { Jumat. }\end{array}$ & Black-box \\
\hline $\begin{array}{l}\text { Panduan } \\
\text { Shalat } \\
\text { Tahiyatul } \\
\text { Masjid }\end{array}$ & $\begin{array}{l}\text { Menampilakan panduan } \\
\text { shalat tahiyatul masjid yang } \\
\text { berisi gambar, bacaan, arti } \\
\text { dan audio bacaan. }\end{array}$ & Black-box \\
\hline $\begin{array}{l}\text { Audio contoh } \\
\text { bacaan }\end{array}$ & $\begin{array}{l}\text { Memainkan audio contoh } \\
\text { bacaan dari shalat tahiyatul } \\
\text { masjid }\end{array}$ & Black-box \\
\hline $\begin{array}{l}\text { Pengertian } \\
\text { Shalat Ju mat }\end{array}$ & $\begin{array}{l}\text { Menampilkan penjelasan } \\
\text { mengenai shalat shalat ju mat } \\
\text { secara berja maah }\end{array}$ & Black-box \\
\hline $\begin{array}{l}\text { Panduan } \\
\text { Shalat Ju mat }\end{array}$ & $\begin{array}{l}\text { Menampilakan panduan } \\
\text { shalat jumat yang berisi } \\
\text { gamabar, bacaan, arti dan } \\
\text { audio bacaan }\end{array}$ & Black-box \\
\hline $\begin{array}{l}\text { Audio contoh } \\
\text { bacaan }\end{array}$ & $\begin{array}{l}\text { Memainkan audio contoh } \\
\text { bacaan dari shalat ju mat. }\end{array}$ & Black-box \\
\hline $\begin{array}{l}\text { Pengertian } \\
\text { Shalat } \\
\text { Ba'diyah } \\
\text { Jumat }\end{array}$ & $\begin{array}{l}\text { Menampilkan penjelasan } \\
\text { mengenai shalat shalat } \\
\text { ba'diyah ju mat. }\end{array}$ & Black-box \\
\hline $\begin{array}{l}\text { Panduan } \\
\text { Shalat } \\
\text { Ba'diyah } \\
\text { Jumat } \\
\end{array}$ & $\begin{array}{l}\text { Menampilakan panduan } \\
\text { shalat ba'diyah jumat yang } \\
\text { berisi gamabar, bacaan, arti } \\
\text { dan audio bacaan }\end{array}$ & Black-box \\
\hline $\begin{array}{l}\text { Audio contoh } \\
\text { bacaan }\end{array}$ & $\begin{array}{l}\text { Memainkan audio contoh } \\
\text { bacaan dari shala ba'diyah } \\
\text { ju mat. }\end{array}$ & Black-box \\
\hline $\begin{array}{l}\text { Menu Doa- } \\
\text { doa }\end{array}$ & $\begin{array}{l}\text { Menampilkan doa-doa } \\
\text { seputar shalat jumat dan } \\
\text { berisikan audio bacaan doa. }\end{array}$ & Black-box \\
\hline $\begin{array}{l}\text { Audio contoh } \\
\text { bacaan }\end{array}$ & $\begin{array}{l}\text { Memainkan audio contoh } \\
\text { bacaan dari doa. }\end{array}$ & Black-box \\
\hline $\begin{array}{l}\text { Menu Set } \\
\text { Alarm }\end{array}$ & $\begin{array}{l}\text { Menampilkan halaman } \\
\text { pengaturan alarm shalat } \\
\text { jumat. }\end{array}$ & Black-box \\
\hline $\begin{array}{l}\text { Menu Arah } \\
\text { Kiblat }\end{array}$ & $\begin{array}{l}\text { Menampilkan halaman arah } \\
\text { kib lat }\end{array}$ & Black-box \\
\hline $\begin{array}{l}\text { Menu } \\
\text { Tentang }\end{array}$ & $\begin{array}{l}\text { Menampilkan halaman } \\
\text { informasi tentang aplikasi }\end{array}$ & Black-box \\
\hline $\begin{array}{l}\text { Tombol } \\
\text { Keluar }\end{array}$ & $\begin{array}{l}\text { Menampilkan notifikasi } \\
\text { keluar aplikasi : ya dan tidak }\end{array}$ & Black-box \\
\hline
\end{tabular}

TABEL 2

TABEL HASIL UJI

\begin{tabular}{|l|l|l|}
\hline \multicolumn{1}{|c|}{ Pengujian } & Metode & Hasil \\
\hline Splash screen & Black Box & Berhasil \\
\hline Menu Utama & Black Box & Berhasil \\
\hline Menu Info & Black Box & Berhasil \\
\hline
\end{tabular}

\begin{tabular}{|l|c|c|}
\hline Menu Pengertian & Black Box & Berhasil \\
\hline Menu Syarat & Black Box & Berhasil \\
\hline Menu Sunah & Black Box & Berhasil \\
\hline Menu Lar angan & Black Box & Berhasil \\
\hline Menu Khutbah & Black Box & Berhasil \\
\hline Menu Urutan & Black Box & Berhasil \\
\hline Menu Panduan & Black Box & Berhasil \\
\hline $\begin{array}{l}\text { Pengertian Shalat } \\
\text { Tahiyatul Masjid }\end{array}$ & Black Box & Berhasil \\
\hline $\begin{array}{l}\text { Panduan Shalat } \\
\text { Tahiyatul Masjid }\end{array}$ & Black Box & Berhasil \\
\hline Audio contoh bacaan & Black Box & Berhasil \\
\hline $\begin{array}{l}\text { Pengertian Shalat } \\
\text { Jumat }\end{array}$ & Black Box & Berhasil \\
\hline $\begin{array}{l}\text { Panduan Shalat } \\
\text { Jumat }\end{array}$ & Black Box & Berhasil \\
\hline Audio contoh bacaan & Black Box & Berhasil \\
\hline $\begin{array}{l}\text { Pengertian Shalat } \\
\text { Ba'diyah Jumat }\end{array}$ & Black Box & Berhasil \\
\hline $\begin{array}{l}\text { Panduan Shalat } \\
\text { Ba'diyah Jumat }\end{array}$ & Black Box & Berhasil \\
\hline Audio contoh bacaan & Black Box & Berhasil \\
\hline Menu Doa-doa & Black Box & Berhasil \\
\hline Audio contoh bacaan & Black Box & Berhasil \\
\hline Menu Set Alarm & Black Box & Berhasil \\
\hline Menu Arah Kiblat & Black Box & Berhasil \\
\hline Menu Tentang & Black Box & Berhasil \\
\hline Tombol Keluar & Black Box & Berhasil \\
\hline
\end{tabular}

\section{KESIMPULAN DAN SARAN}

\section{A. Kesimpulan}

Berdasarkan hasil penelitian, maka dapat diambil ksimpulan sebagai berikut.

1. Aplikasi Pembelajaran Tatacara Shalat Jumat mudahdijalakan untuk pengguna ponsel cerdas Android.

2. Aplikasi Pembelajaran Tatacara Shalat Jumat bermanfaat untuk med ia pe mbelajaran shalat Ju mat.

3. Berdasarkan pengujian pada Aplikasi Pembelajaran Tatacara Shalat Jumat, tampilan pada aplikasi menarik untuk media pembelajaran.

4. Aplikasi Pembelajaran Tatacara Shalat Jumat Berbasis Android ini dapat berjalan dengan baik pada perangkat dengan sistem operasi Android minimal versi 4.0 (Ice Cream Sandwitch) sesuai dengan hasil percobaan dengan kapasitas penyimpanan yang tersedia minimal 7 MB.

5. Tombol-tombol dan fungsi-fungsi yang terdapat pada aplikasi dapat berfungsi dengan baik dan sesuai dengan fungsionalitasnya masing-masing.

\section{B. Saran}

Berdasarkan hasil pengujian aplikasi dunia hewan untuk pembelajaran anak usia dini, dapat diberikan beberapa saran sebagai berikut.

1. Aplikasi Pembelajaran Tatacara Shalat Jumat Berbasis Android perlu dikembangkan lagi dengan menambah materi khutbah .

2. Aplikasi Pembelajaran Tatacara Shalat Jumat akan lebih baik apabila ada penambahan fitur-fitur yang lebih menarik misalnya mengetahui lokasi masjid terdekat.

3. Aplikasi Pembelajaran Tatacara Shalat Jumat Berbasis Android akan lebih baik apabila dikembangkan juga sebagai aplikasi cross-platform. 


\section{DAFT AR PUST AKA}

[1] Ableson, W.F., Android in Action, Shelter Island, NY: Manning, 2012.

[2] Cinar, O., Android Apps with Eclipse, Apress,Jakarta, 2012.

[3] Darytamo, Budi, Sri Widayanti., Pem rograman Berorientasi Obyek dengan Java 2 Platform Micro Edition ( J2ME ), Java Competency Center-IT B, Bandung, 2007.

[4] Jabir, A.Q.A., Jumatan Bersama Nabi, Aqwam, Solo, 2011.

[5] Pilone, B.D. \& Pitman, N., UML 2.0 in a Nutshell, Sebastopol: O'Reilly,2005.

[6] Prabawati, T.A. (Ed)., Tutorial 5 Hari Membangun GUI dengan JAVA Netbeans 6.5, Andi, Yogyakarta. 2010.

[7] Pressman, Roger S, Rekayasa Perangkat Lunak (Pendekatan Praktis), Andi, Yogyakarta, 2002.

[8] Putra, A.A., "Praktis Android A-Z”, Lubuklinggau, 2012.

[9] Safaat H, N., ANDROID Pemrograman Aplikasi Mobile Smartphone dan Tablet PC berbasis Android, Informatika, Bandung, 2011.

[10] Siregar, I.M., "Membongkar Source Code berbagai Aplikasi Android", GAVA MEDIA, Yogyakarta, 2011.

[11] Syaiful Sagala., Konsep dan Makna Pembelajaran, CV.ALFABET, Bandung, 2009.

[12] Thohari, A.N.A., "Pembuatan Aplikasi Mobile Learning Sebagai Sarana Pembelajaran di Lingkungan Universitas Diponegoro", Jurnal Sistem Komputer Undip, pp.1-11, 2013.

[13] Wibowo. A., Kumpulan Khutbah Jumat Motivasi dan Inspiratif, Gala Ilmu Semesta, Yogyakarta, 2011.

[14] Yasin, V., Rekayasa Perangkat Lunak Berorientasi Objek, Mitra Wacana Media, Jakarta, 2012. 


\section{Daftar Penulis}

- $\mathrm{A} \quad 1-$

Apridianto, Angga . 362 一 C I

Cahyono, Mohammad Dwi...370 - $D$ D $/$

Defrianto, Dony ........... 379

Desyantoro, Eka ......... 405

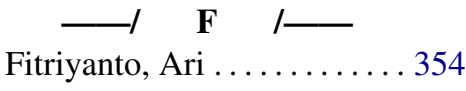

$\underset{\text { Isnanto, R. Rizal . ........4412 }}{\text { I }}$
- $\quad \mathbf{K}$

K I-

Kridalukmana, Rinta . . 335, 370, $379,393,412$

399, 405

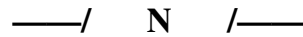

Nurhayati, Oky Dwi . . . 343, 399

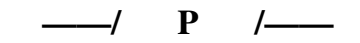

Prasetya, Penji ............ 387

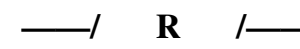

Raharjo, Suryo Mulyawan . 399
Rahmawati, Annisa ....... 335

Renatha, Febi Andrea .... . . 343

Rochim, Adian Fatchur 387, 405

Satoto, Kodrat Iman . . . 343, 354, 362,370

Setiawan, Andhi .......... 393

Setiyawan, Ferry Dwi ..... 412

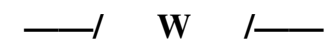

Windasari, Ike Pertiwi. 335, 362, $379,387,393$ 
